\title{
6. 胃食道逆流症（GERD）と喘息
}

\author{
土橋 邦生 \\ (群馬大学医学部保健学科)
}

胃食道逆流症 (GERD) は, 逆流性食道炎も 含め, 胃の内容物が食道に逆流するために生じ る一連の症候と定義されている。呼吸器疾患と 胃食道逆流（GERD）との関連性については, 最近, 慢性咳嗽, 喘息や睡眠時無呼吸症候群な どにおいて検討した報告が増加している。喘息 患者において, GERD は, 喘息症状を出現させ, しかも, 高率に合併している。特にコントロー ル不良の喘息患者の中には, GERD があること に気づかないことがあるため，喘息治療の盲点 となっている。

診断には QUEST 質問表や内視鏡検査, 24時 間 $\mathrm{pH}$ モニタリングなどが用いられる。簡便な 患者自己記入式の QUEST 質問表は，スコア 4 以上で70\%以上の GERD を診断でき, 高い感 受性を示す。喘息患者37例と非喘息患者40例に QEST 質問表を実施したところ，スコア 4 以上 の割合がそれぞれ $62.1 \%, 37.5 \%$ ，喘息患者 で有意に高かった。胃内視鏡診断では，50歳以 上の外来患者145例中, GERDの所見の見られ た率は全患者において $57.2 \%$ であったが，喘息

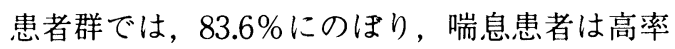
にGERDの所見を持つことがわかった。24時 間 $\mathrm{pH}$ モニタリングによる診断は，鼻腔より電 極を挿入し食道下端部の $5 \mathrm{~cm}$ 口側に固定し, そこの $\mathrm{pH}$ を測ることにより, 胃酸の逆流を測 定する方法である。GERD の診断のゴールデン スタンダードであるが, 被検者への負担も大き く, 全症例には施行できないので, 胃内視鏡所
見陰性喘息患者で, GERD の症状があり, 食道 への酸の逆流を証明したい時などに使用すると よいと思われる。内視鏡的には，喘息患者の39 \%に食道びらんや潰瘍がみとめられたが, $\mathrm{pH}$ モニター法では，82\%に酸の逆流をみとめたと の報告もある。

GERD をもつ喘息患者にGERDの治療を行 うことにより，喘息症状は軽減されることが予 想される。喘息患者を封筒法により PPI と H2 投与群にわけ1 月月間投与し，ピークフロー值 で観察したところ，PPI を投与した患者ではピ ークフローの改善が観察された。

喘息の治療薬として使われる，6刺激剤やテ オフィリンは筋弛緩剂として下部食道平滑筋 （LES）に作用し LES 圧を低下させ GERD を 惹起しやすくしている可能性もあり, これら薬 剤を他の薬剤に変更することも考慮にいれる必 要がある。

現在, GERD が喘息の症状の悪化や難治化に 関係しているか否かに関して,検討段階である。 しかし，文献的にも我々のアンケートや内視鏡 検査の結果をみても, 喘息患者群では GERD を持つ患者が多いこと，また，プロトンポンプ インヒビターが喘息症状の改善に有効な例があ ることも事実である。とくに通常の治療に抵抗 性の喘息おいて, GERDの検査をおこなってみ ることが重要であり, GERD があれば治療を検 肘すべきである。 